\title{
The persistence of family firms: How does performance threshold affect family firm exit?
}

\author{
Noni Symeonidou • Dawn R. DeTienne • Francesco Chirico
}

Accepted: 18 February 2021 / Published online: 10 May 2021

(C) The Author(s) 2021

\begin{abstract}
Research on family firms provides mixed evidence of the effect of family ownership on firm performance and exit outcomes. Drawing on threshold theory and the socioemotional wealth perspective, we argue that family firms have lower performance thresholds than non-family firms, reducing the likelihood of firm exit. Using a longitudinal dataset of 1191 firms over the period 2008-2011, we find support for this contention, suggesting that performance threshold is an important, yet poorly studied, construct for understanding exits of family versus non-family firms.
\end{abstract}

Plain English Summary Why firms with similar economic performance make different exit decisions? We find evidence that family firms have lower "performance thresholds" than non-family firms, reducing family firms' likelihood of exit. Using a longitudinal dataset, we examine differences in performance threshold between family and non-family firms and help clarify why some firms persist with their ventures even though their performance may indicate they should exit the market. Our theory and related findings suggest that

N. Symeonidou

Warwick Business School, University of Warwick, Coventry CV4 7AL, UK

e-mail: noni.symeonidou@wbs.ac.uk

\section{R. DeTienne}

College of Business, Colorado State University,

Fort Collins, CO 80528, USA

e-mail: dawn.detienne@colostate.edu nonfinancial attributes such as identity, the ability to exercise family influence, and to hand the business down to future generations may affect family firms' attitudes toward exit decisions. Our study contributes to sharpening our understanding of exit in family firms while motivating future work on exit strategies in family firms and other contexts.

Keywords Family firm · Firm exit · Firm Persistence . Performance threshold

JEL classification $\mathrm{L} 26 \cdot \mathrm{M} 13$

\section{Introduction}

Research on family firms provides mixed evidence for the effect of family ownership on firm performance and exit strategies (Siebels and $\mathrm{Zu}$ Knyphausen-Aufseß, 2012). One explanation may be that firms' performance only partially explains exit decisions (Guenther et al., 2016; Wennberg et al., 2010), as entrepreneurs base

\section{F. Chirico}

Department of Management, Macquarie Business School Macquarie University, 4 Eastern Road, Sydney, NSW 2109, Australia

\section{F. Chirico $(\bowtie)$}

Center for Family Entrepreneurship and Ownership - CeFEO, Jönköping International Business School - Jönköping University, PO Box 1026, SE-551 11 Jönköping, Sweden

e-mail: francesco.chirico@mq.edu.au 
their decisions on many factors (Taylor, 1999; Wolfe and Patel, 2019) and "performance is only one - and not necessarily the most important - determinant of organizational survival" (Meyer and Zucker, 1989, p. 9). Thus, the simple "poor performance leads to exit" model is underspecified and provides inadequate insights into family firms' exit decisions.

However, research shows that exit is important, because "shedding resource combinations that no longer add value-creating opportunities is a critical dynamic capability in Schumpeterian markets, and an important component of the entrepreneurial process" (Salvato et al., 2010, p. 321). Yet it is particularly challenging for owners of family firms to realize that perpetuating their business is only one possibility among many (Chirico et al., 2018; Kaye, 1998). Family firms' exit decisions are influenced by factors such as emotional attachment, long-term orientation, and strong family ties (Akhter et al., 2016; Chirico et al., 2020). Scholars observe that, when making strategic decisions, the primary reference point in family firms is loss of socioemotional wealth (SEW), or the stock of affectrelated value that the family has invested in the firm (Berrone et al., 2012; Gómez-Mejía et al., 2007). Therefore, family firms may base exit decisions not purely on economic performance, but also on their own economic and/or non-economic performance thresholds (Gimeno et al., 1997; Siepel et al., 2017).

Threshold theory posits that exit is not strictly dependent on financial performance, but on performance relative to a firm-specific threshold (Gimeno et al., 1997). Decision-makers with higher performance thresholds may exit from the market if firms do not meet their financial expectations, whereas those with lower performance thresholds may persist with poor- or underperforming firms (DeTienne et al., 2008; Gimeno et al., 1997). The threshold perspective helps explain why firms with similar economic performance make substantially different exit decisions. Our study extends previous research (e.g., DeTienne and Chirico, 2013; Chirico et al., 2020) by examining performance thresholds in family versus non-family firms and the role of performance thresholds as an underlying mechanism linking family firms and their exit decisions. Given the different economic and non-economic priorities pursued by family and non-family firms (Hoskisson et al., 2017), understanding how performance thresholds affect exit is key to understanding exits in family firms. Our theory draws on the SEW perspective that leads family firms to exhibit lower performance thresholds and thus lower likelihoods of exit than non-family firms.

Using a longitudinal dataset of 1191 firms over the period 2008-2011 (Kauffman Firm Survey, KFS), we test the relationships surrounding performance thresholds and family firm exit and argue that, as a result of socioemotional benefits, family firms have lower thresholds than non-family firms and are thus more willing to persist with their businesses. Our empirical findings support our hypotheses. As such, our research contributes to current literature in three ways. First, we build on threshold theory by identifying a specific context with differing performance thresholds. Our results support Gimeno et al.'s (1997) work by providing empirical evidence of differing performance thresholds between family and non-family firms. Our study is also one of the first to test the concept of thresholds as an underlying mechanism in family firms' decision-making. While the threshold concept is used extensively in other literature (e.g., pain, hearing, and risk thresholds), our work tests the efficacy of its application to management and entrepreneurship.

Second, our work contributes to understanding family firm exit by identifying performance thresholds as a crucial mediating mechanism, thereby helping to explain why family firms are willing to persist with below-target performance. We demonstrate that family firms have lower performance thresholds than nonfamily firms and that these decrease the likelihood of exit, thus explaining differences in overall performance rates between family and non-family firms. Our study also sheds light on factors contributing to family firm exit (Chirico et al., 2020; Salvato et al., 2010; Wilson et al., 2013), thereby responding to recent calls to expand studies of family firm exit beyond founders' succession (DeTienne, 2010; DeTienne and Chirico, 2013; Shepherd, 2009; Ucbasaran et al., 2013; Wennberg et al., 2010). Finally, we demonstrate that investigating differences in performance thresholds between family and non-family firms may have important implications for a growing body of exit research on the persistence of under-performing firms. Under-performing firms impose costs on the economic system, use resources inefficiently, and increase uncertainty for competitors, investors, and employees (DeTienne et al., 2008). Understanding threshold differences between family and non-family firms may help identify other important contexts and factors that lead to differing thresholds of firm performance, which may have a lasting impact on 
exit decisions. We discuss these and suggest avenues for future research.

\section{Theoretical background and hypotheses}

The question of whether family firms perform better and persist longer than non-family firms has recently attracted renewed research attention (Chirico et al., 2020; Gedajlovic et al., 2012; Gómez-Mejía et al., 2007; Wilson et al., 2013), producing mixed results. Research showing positive family effects suggests that family firms avoid agency problems, are extra vigilant with resources, have a culture of commitment to longterm objectives, scrutinize opportunities with greater intensity, have access to wider social networks and family resources, and have greater tacit or embedded knowledge (Cruz and Nordqvist, 2012; Gedajlovic et al., 2012; Kellermanns and Eddleston, 2006; Ling and Kellermanns, 2010; Salvato, 2004). From a purely economic performance perspective, these results suggest that family firms will outperform and survive longer than non-family firms. However, other research indicates that controlling families may use their control for private benefit rather than to maximize firm value, are less likely to reward non-family executives with performance-related incentives (for fear of diluting family control), favor family members for promotion rather than selecting the most qualified individuals, are less competitive, may be subject to intra-family conflict, are less innovative, and have weaker governance systems (Gedajlovic et al., 2012; Kellermanns et al., 2012; Mazzola et al., 2013). These "negative" factors suggest that family firms may underperform relative to nonfamily firms and on purely economic performance grounds should be selected out of the market. Thus, it appears that many positive and negative factors affect family firms' performance and exit.

Threshold theory offers a different explanation that may help to reconcile these findings, as it suggests that firm exit is not strictly dependent on economic performance, but on performance relative to a firm-specific threshold (Gimeno et al., 1997; Siepel et al., 2017). Gimeno et al. (1997, p. 750) define performance threshold as "the level of performance below which the dominant organizational constituents will act to dissolve the organization." The scant research on thresholds reveals that they are impacted by whether a firm has objectives other than (or in addition to) firm performance (Gimeno et al., 1997). For example, a founder's identity may be so tightly linked with the firm that (s)he may decide to persist despite poor performance, rather than dealing with the loss of identity and "self" associated with the firm. Using Staw's (1981) commitment to a course of action perspective, DeTienne et al. (2008) identify environmental, organizational, and founder factors that have an impact on firms' performance thresholds and ultimately persistence decisions. Green et al. (2003) find that product development projects may be terminated early or prolonged owing to threshold effects. Although limited, these studies provide early evidence that thresholds affect exit decisions.

Relatedly, rather than focusing on financial results, some research has analyzed decision-making in family firms through the lens of behavioral agency (Wiseman and Gomez-Mejia, 1998), embracing the concepts of loss aversion (decision-makers tend to minimize losses) and risk bearing (perceived wealth at risk of loss makes decision-makers risk averse). This literature argues that SEW- "the nonfinancial aspects of the firm that meet the family's affective needs, such as identity, the ability to exercise family influence, and the perpetuation of the family dynasty" (Gómez-Mejía et al., 2007, p. 106) - is an important endowment that family owners seek to protect, even when it leads to suboptimal financial decisions (see Berrone et al., 2010; Chrisman and Patel, 2012; Deephouse and Jaskiewicz, 2013; Gómez-Mejía et al., 2007, 2010, 2011; Zellweger et al., 2011). We next examine how non-economic motives and thresholds affect exit decisions in family firms.

\subsection{Family firms and performance thresholds}

The SEW perspective provides initial insights into differing performance thresholds in family and non-family firms. Berrone et al. (2012, p. 258) note that "SEW is the most important differentiator of the family firm as a unique entity and, as such, helps explain why family firms behave distinctively." SEW is composed of five elements: family control and influence, family member identification with the firm, binding social ties, emotional bonds, and the intention to hand the business down to future generations (Berrone et al., 2012). We examine each element and its potential impact on performance thresholds.

Family control and influence refer to family members' desire to maintain both ownership and managerial 
control over strategic decisions and strategic positions (e.g., CEO and board of directors) (Chua et al., 1999; Zellweger et al., 2011). This desire may outweigh performance considerations (Gómez-Mejía et al., 2007), and family firms may choose to give up potential income-generating activities likely to result in loss of control, suggesting a willingness to establish lower performance thresholds.

The second dimension of SEW is family members' identification with the firm as an extension of the family (Berrone et al., 2010). Thus, strategic decisions within the firm impact the family's reputation, and decisionmakers are careful to make decisions that reflect positively on the family image (Sharma and Manikutty, 2005). This concern for the family's reputation may make family decision-makers less willing to accept risk or engage in the entrepreneurial activities necessary to compete and develop competitive advantage (Covin and Miles, 1999). Previous research confirms that family firms engage less in entrepreneurial activities and enter fewer markets than non-family firms do (Block, 2012; Graves and Thomas, 2004). This suggests that such firms may be more content with lower performance thresholds.

The third component of SEW refers to family firms' binding social ties (Berrone et al., 2012). Kinship ties strengthen family members' commitment to the firm. Research also demonstrates that such ties may spill over to long-standing customers and suppliers (Uhlaner, 2006) but make it more difficult for the firm to reduce its assets or relationships. In the presence of strong ties, family firms may accept weaker performance from family members and may be less willing to raise prices for long-standing customers or demand higher standards from long-standing suppliers.

Emotional attachment is the fourth dimension of SEW. While all organizations exhibit a degree of emotional attachment, the psychological ownership literature indicates that emotional attachment is stronger when there is a shared history and knowledge of shared experiences (Pierce et al., 2003). Families who share long histories and involvement are likely to have stronger emotional attachment to the firm: "Because the boundaries between family and corporation are rather blurred in family businesses ... emotions permeate the organization, influencing the family firm's decisionmaking process" (Berrone et al., 2012, p. 263). This may lead to a willingness to accept lower performance in order to preserve the relationship.
The final dimension of SEW is the intention for family members of successive generations to take over the firm, thereby creating a sense of dynasty. Because the firm must be preserved for future generations, it symbolizes much more than an asset to be used or sold: the family firm must be preserved at all costs. As Akhter (2016) demonstrates, family firms may close successful satellite businesses in order to move resources to sustain the primary family business.

In summary, in family firms, the most important objective in strategic decisions is to preserve SEW. The five dimensions of SEW suggest that, compared with non-family firms, family firms are more willing to give up potential income-generating activities and thus accept lower performance thresholds. In formal terms:

Hypothesis 1: Family firms exhibit lower performance thresholds than non-family firms.

Furthermore, we expect performance thresholds to mediate the relationship between family firms and exit, such that, owing to their lower performance aspirations, family firms will be more likely to remain in business than non-family firms will. Many studies corroborate this posited relationship, suggesting that family firms are motivated primarily by nonfinancial objectives, often leading to escalation of commitment (Chirico et al., 2018; Sharma and Manikutty, 2005; Sirmon and Hitt, 2003). Commitment to nonfinancial goals makes family firms more willing to accept lower economic returns (Gimeno et al., 1997; Gómez-Mejía et al., 2007; Zellweger et al., 2013) and be prepared to commit extra resources such as patient and survivability capital to persist with the activity (Chirico et al., 2011; Sirmon and Hitt, 2003).

Relatedly, other studies suggest that family firms tend to view their businesses not only as sources of income but also as contexts for family activity and embodiment of pride and identity (Gimeno et al., 1997; Meyer and Zucker, 1989; Zellweger et al., 2013). For example, Meyer and Zucker (1989, p. 79) argue that, given multiple goals that may divert from profit maximization, family firms' continuation 'becomes an important goal - it is important to continue the family control, regardless of the profit motive"; thus, these firms are less likely to exit. Similarly, Gimeno et al. (1997, p. 758) and Francis and Sandberg (2000) argue that when entrepreneurs are motivated by noneconomic goals, such as family affective bonds, they 
gain a greater "psychic income from entrepreneurship" and are therefore willing to accept lower economic returns (and thus lower thresholds) while continuing the business. Thus, we hypothesize that:

Hypothesis 2: Performance threshold mediates the relationship between family firms and exit such that family firms have a lower likelihood of exit than non-family firms.

\section{Data and methods}

\subsection{Sample}

Our study used longitudinal data from the KFS and, in particular, the proprietary dataset of US firms. This panel was formed from a random sample of 32,469 firms from Dun and Bradstreet's database of all firms formed in the USA in 2004, excluding non-profit firms, those owned by an existing business and firms inherited by someone else (DesRoches et al., 2010). Our sample included panel data from 2008 to 2011 (1191 firms in total) since information on family ownership was not introduced until 2008. Firms with only one owner were excluded. About 30 percent of the companies in our sample were family firms. The firms had nine employees on average, and around a third had exited by the end of the last year of our panel data.

Compared with many firms in the family firm literature, our sample consisted of younger firms (between 4 and 8 years of age, with a mean of 5.3), making this an interesting and relevant sample for two reasons. First, these firms were likely to have been intended to be family firms from the outset (rather than bringing in a family member as the first generation ages). Thus, from the beginning, these firms had been immersed in the family decision-making process. Second, we believe that if we find support for our hypotheses in young family firms, the effect may be even stronger in longer established family firms, unless (family) commitment vanishes.

The KFS is particularly well suited to studying exit in family firms. First, we had uninterrupted information on the sampled firms from the first year of founding, allowing us to make use of the panel nature of the dataset and test exit rates (Geroski et al., 2010). Second, this dataset provides information on alternative exit outcomes, such as mergers and acquisitions (M\&As) and permanent closures, allowing us to conduct post hoc analyses of different exits (Shah and Winston Smith, 2012). Third, this dataset not only tracks the firm's year of exit in detail but also gives information on its performance threshold, as well as its yearly economic performance, which is typically difficult to obtain from private firms. Thus, we were able to measure firm threshold systematically and test whether firms with equal economic performance were more or less likely to exit. According to Gimeno et al. (1997, p. 763), when ventures have equal economic performance, the incidence of exit can be attributed to performance threshold differences.

\subsection{Measures}

\subsubsection{Dependent variable}

Exit The dependent variable is defined as the probability that a firm will exit (closure) in a given year. This binary variable equals 0 when the firm is in operation and 1 when the firm is no longer in business (Audretsch and Mahmood, 1995; Dencker et al., 2009; Geroski et al., 2010; Gimeno et al., 1997). As a robustness test, we also focused on other modes of exit such as M\&As (see DeTienne et al., 2015).

\subsubsection{Independent variables}

Family firm Several scholars define family firms as those in which a family has a significant ownership stake (Chirico et al., 2011; Sirmon et al., 2008). Similarly, we measured family firm with a binary variable that equals 1 if a family owns more than 50 percent of the firm and 0 otherwise. We obtained this information from the KFS.

Performance threshold As thresholds are not observable (Gimeno et al., 1997), we relied on a perceptual measure of the extent to which owners had met their expectations for growth while controlling for economic performance. Thresholds of performance are inherently perceptual (Mortara and Parisot, 2018), based on decision-makers' own sense of acceptable levels of 
performance. The KFS asked founders "how much do you think your business met your expectations for growth in the last three years?" (DesRoches et al., 2010, p. 81). The possible responses were "exceeded" (coded as 1), "met" (coded as 2), and "did not meet" expectations (coded as 3). Controlling for firm performance, and all else being equal, owners who feel they have met or exceeded their expectations and yet exit the market are more likely to have low performance thresholds, whereas owners who feel they have not met their expectations and have exited are more likely to have high thresholds (Gimeno et al., 1997).

\subsubsection{Control variables}

We controlled for characteristics of the founder (start-up experience, industry experience, college degree), firm (economic performance, size of firm [number of employees], whether it had received venture capital funding), and industry (high-tech) that might potentially influence the likelihood of exit. Founders' previous start-up experience may negatively influence firm exit, as serial entrepreneurs may have gained knowledge from setting up a business and developing new products, as well as managing early-stage organizations (Shane and Stuart, 2002). We measured start-up experience by summing the number of previous businesses created across owners and taking the log of this number. We measured previous industry experience with a binary variable that equals 1 when owners had previous experience of starting a venture in the same industry and 0 otherwise. Companies founded by individuals with industry-specific start-up experience are expected to perform better, having gained important skills and valuable contacts with customers, suppliers, and investors in the industry (Shane and Stuart, 2002). We controlled for owner's education with a binary variable that equals 1 when the owner had a college degree and 0 otherwise (Geroski et al., 2010).

We used a continuous variable to measure economic performance by taking the log of the revenues that the firm had generated. We controlled for the size of the firm by taking the natural logarithm of the total number of employees and owners of the business (Geroski et al., 2010). In addition, we controlled for access to venture capital (VC) with a binary variable that equals 1 if the firm had received VC funding and 0 otherwise (Stuart et al., 1999). Our measure of high-tech industry, adapted from Hecker's (2005) definition of high-technology industries, is a dummy variable indicating whether firms competed in high-technology areas (Hecker, 2005). ${ }^{1}$ Finally, we also included industry dummies. We used the "construction" industry as a comparator, with dummy variables for manufacturing, finance, scientific services, wholesale and retail trade, information, real estate and accommodation and food services, healthcare, and other service industries. All independent and control variables were lagged by 1 year.

\subsection{Model and econometric approach}

Survival analysis is widely employed to examine firm exit (Audretsch and Mahmood, 1995; Dencker et al., 2009; Geroski et al., 2010; Gimeno et al., 1997; Shah and Winston Smith, 2012). This methodology allowed us to study how firms' exit rates evolved over time. We estimated the exit model using censored data grouped into yearly intervals. The Cox proportional hazard model is a semi-parametric model in which no assumption is made regarding the underlying distribution of the baseline hazard (Cox, 1972). This allowed us to define exit more rigorously than conventional approaches such as probit or logit analysis (Wooldridge, 2001). Thus, the Cox model of firm $i$, industry $j$ and entrepreneur $k$ takes the form:

$$
\begin{aligned}
& \mathrm{h}_{\text {exit }}\left(\mathrm{t}, \mathrm{F}_{\mathrm{i}}, \mathrm{P}_{\mathrm{k}}, Z_{\mathrm{i}, \mathrm{j}, \mathrm{k}}\right) \\
& \quad=\mathrm{h}(\mathrm{t}) \operatorname{ep}\left({ }_{\mathrm{o}}+\beta_{\varphi} \mathrm{F}_{\mathrm{i}}+\beta_{\pi} \mathrm{P}_{\mathrm{k}}+\beta_{\mathrm{z}} \mathrm{Z}_{\mathrm{i}, \mathrm{j}, \mathrm{k}}\right)
\end{aligned}
$$

where $h_{\text {exit }}$ is the instantaneous rate of firm exit conditional on survival until time $t, F_{i}$ indicates the family ownership of $i, P_{k}$ is the performance threshold of $k$, and $Z_{i, j, k}$ is a vector of attributes of entrepreneur $k$, firm $i$, and industry $j$. All covariates were updated yearly through the inclusion of their (1 year) lagged values. We

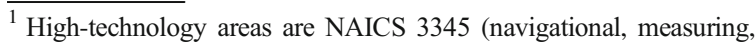
electromedical, and control instruments), NAICS 3254 (pharmaceutical and medicine manufacturing), NAICS 3341 (computer and peripheral equipment manufacturing), NAICS 3342 (communications equipment manufacturing), NAICS 3344 (semiconductor and other electronic component manufacturing), NAICS 3332 (industrial machinery manufacturing), NAICS 3335 (metalworking machinery manufacturing), NAICS 5417 (scientific research and development services), NAICS 5415 (computer systems design and related services), NAICS 5112 (software publishers), NAICS 3346 (manufacturing and reproducing magnetic and optical media), NAICS 3359 (other electrical equipment and component manufacturing), NAICS 3364 (aerospace product and parts manufacturing), NAICS 3329 (other fabricated metal product manufacturing), and NAICS 3251 (basic chemical manufacturing).
} 
therefore took account of the influence of time-variant explanatory variables on firms' survival rate by modeling the probability of exit at time $t$ as a function of entrepreneur $k$, firm $i$, and industry $j$ observed at $t-1$. In addition, we employed a random effects ordered logistic regression to examine differences in thresholds between family and non-family firms (Rabe-Hesketh and Skrondal, 2008).

\section{Results}

Table 1 presents descriptive statistics and correlations for the variables. Thirty-five percent (417) of the firms had exited by year seven. On average, the firms had nine employees, and the founders had previously started two businesses. About 30 percent of firms were family owned, around 60 percent of firm owners had a college degree, and only one percent of firms had secured VC funding. Approximately 14 percent of firms were operating in a high-tech industry, and the average annual turnover (sales) was more than $\$ 2$ million. A $t$-test analysis revealed that, in our sample, family firms had fewer employees and lower performance thresholds and were less likely to have received VC funding than nonfamily firms were. ${ }^{2}$

Table 2 presents the results of the Cox proportional hazard estimation. The first model of Table 2 includes the control variables. In model 2 , we find that family firms $(\beta=-0.94, p<0.001)$ were less likely to exit than non-family firms. To test hypothesis 1 , we performed an ordinal logistic regression (model 3). We find that family firms were (marginally) less likely to have a high performance threshold $(\beta=-0.20, p<0.1)$, thus providing some support for hypothesis 1 . To test hypothesis, 2 we followed the multi-stage approach suggested by Baron and Kenny (1986). We tested the effect of being a family firm on firm exit (model 2), the effect of the family firm on performance threshold (model 3 ), and the effect of performance threshold on firm exit while controlling for the family firm (partial or full mediation, model 4).

Our results for models 2 to 4 confirm that performance threshold is a partial mediator of the family/exit relationship, thus providing general support for hypothesis 2. In fact, the performance threshold variable is positively related to exit as it increases the hazard rate

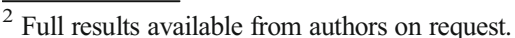

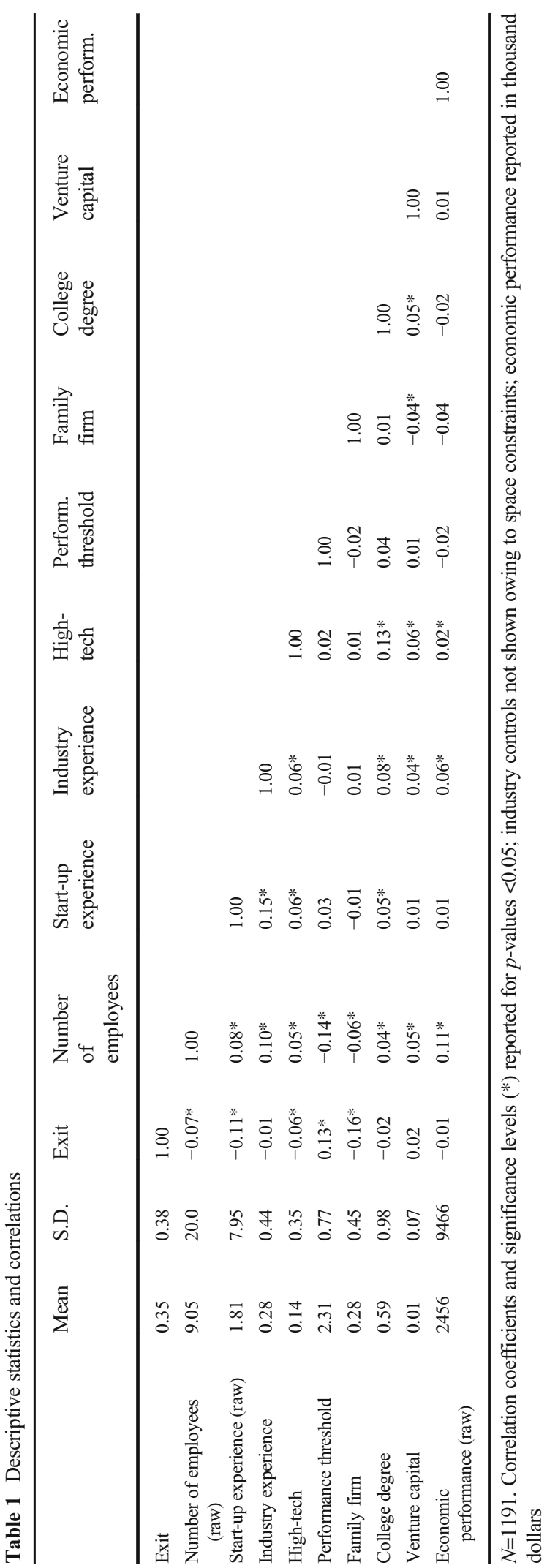


Table 2 Panel data analysis

\begin{tabular}{|c|c|c|c|c|}
\hline & (1) & (2) & (3) & (4) \\
\hline & Exit & Exit & Performance threshold & Exit \\
\hline Economic performance & $-0.12 * * *(0.02)$ & $-0.13 * * *(0.02)$ & $-0.24 * * *(0.05)$ & $-0.15 * * *(0.04)$ \\
\hline College degree & $-0.08(0.09)$ & $-0.05(0.10)$ & $0.35^{*}(0.15)$ & $-0.12(0.18)$ \\
\hline Number of employees & $-0.44 * * *(0.10)$ & $-0.40 * * *(0.09)$ & $-0.11(0.11)$ & $-0.10(0.17)$ \\
\hline Start-up experience & $-0.08(0.07)$ & $-0.10(0.08)$ & $0.14(0.10)$ & $-0.16(0.14)$ \\
\hline Industry experience & $0.19(0.13)$ & $0.19(0.12)$ & $0.15(0.18)$ & $0.31(0.23)$ \\
\hline Venture capital & $1.46^{* * *}(0.45)$ & $1.25 * *(0.46)$ & $1.10(1.21)$ & $-32.02 * * *(0.67)$ \\
\hline High-tech & $-0.14(0.17)$ & $-0.12(0.16)$ & $0.23(0.24)$ & $-0.47(0.37)$ \\
\hline Manufacturing & $-0.07(0.15)$ & $-0.06(0.15)$ & $0.14(0.24)$ & $-0.11(0.30)$ \\
\hline Finance & $-0.02(0.27)$ & $-0.08(0.27)$ & $-0.31(0.44)$ & $0.05(0.41)$ \\
\hline Scientific services & $0.02(0.14)$ & $0.06(0.14)$ & $-0.27(0.23)$ & $-0.07(0.26)$ \\
\hline Wholesale & $-0.35(0.25)$ & $-0.35(0.25)$ & $-0.24(0.33)$ & $-0.72(0.57)$ \\
\hline Retail & $0.29+(0.15)$ & $0.38 *(0.15)$ & $0.26(0.29)$ & $0.15(0.31)$ \\
\hline Information & $-0.53(0.36)$ & $-0.53(0.35)$ & $0.14(0.44)$ & $-0.45(0.73)$ \\
\hline Real estate & $-0.34(0.25)$ & $-0.30(0.25)$ & $-0.26(0.36)$ & $-0.84(0.70)$ \\
\hline Accommodation and food services & $0.44(0.34)$ & $0.56 *(0.35)$ & $-0.37(0.54)$ & $0.68(0.53)$ \\
\hline Other services & $-0.42+(0.24)$ & $-0.36(0.24)$ & $-0.08(0.34)$ & $0.19(0.32)$ \\
\hline Healthcare & $0.48(0.31)$ & $0.61 *(0.31)$ & $-0.54(0.67)$ & $0.52(0.67)$ \\
\hline Performance threshold & & & & $0.45 * *(0.15)$ \\
\hline Family firm & & $-0.98 * * *(0.13)$ & $-0.20+(0.15)$ & $-0.68 * *(0.22)$ \\
\hline Firms & 1191 & 1191 & 702 & 686 \\
\hline Observations & 2778 & 2778 & 702 & 686 \\
\hline Log likelihood & -2674.55 & -2645.53 & -688.40 & -640.37 \\
\hline Prob $>$ chi2 2 & 0.0000 & 0.0000 & 0.0000 & 0.0000 \\
\hline
\end{tabular}

Robust standard errors clustered on the firm cited in the Cox models predicting exit; one-tailed tests for hypothesized relationships; $* * *$ $p<0.001, * * p<0.01, * p<0.05,+p<0.1$

by $0.45(p<0.01)$, while family firm is negatively related to exit and its effect is reduced $(\beta=-0.68, p<0.01)$.

\subsection{Robustness tests}

We conducted several robustness checks to ensure the accuracy of our results and checked the sensitivity of our results to different specifications. First, we tested a multinomial logistic regression and distinguished between multiple outcomes, i.e., continuation, exit by closure, and exit by M\&A (Chirico et al., 2020). The results of this regression, with continuation as the base outcome, show that family firms had lower incidences of exit by closure $(\beta=-1.17, p<0.001)$ and M\&A $(\beta=-1.03), p<0.01)$ than non-family firms (twotailed tests). Second, we tested the effect of being a family firm on financial performance outcomes and, as expected, found that family firms performed worse than non-family firms, yet exited less. This finding corroborates our theory that family firms may have lower performance thresholds driven by non-economic motives, so although they perform worse, they exit less.

Third, to test whether differences in actual performance might affect our findings, we added a continuous, time-varying variable that controlled for the revenues generated by firms in year $t-1$. Fourth, we tested the robustness of the results by using different econometric models. We employed probit, logit, and cloglog models to check whether our results were sensitive to model specifications. None of the results differed from those reported.

Finally, we performed the Sobel test to establish whether the effect of being a family firm significantly decreased with the addition of a performance threshold (Baron and Kenny, 1986; Sobel, 1982). This revealed that performance threshold mediates the negative effect 
of being a family firm on propensity to exit. We also ran analyses for mediation in structural equation modeling, which were consistent with the results reported above.

\section{Discussion}

\subsection{Key findings and implications}

In this study, we employed a semi-parametric hazard model to compare the exit rates of family and nonfamily firms, using a large sample of 1191 private firms operating in a range of industries. Our examination of differences in performance threshold between family and non-family firms reveals that family firms have lower performance thresholds than non-family firms and that high performance thresholds are associated with a greater likelihood of exit. Performance thresholds mediate the relationship between family firms and exit, such that family firms have lower performance thresholds, which decrease the likelihood of exit. These results are robust to different specifications of exit and the presence of controls such as economic performance.

Our work directly tests DeTienne and Chirico's (2013) arguments and extends Chirico et al.'s (2020) work by offering a more tailored theory of family firm exit that combines Gómez-Mejía et al.'s (2007) SEW perspective with Gimeno et al.'s (1997) performance threshold logic. Specifically, our study offers a first attempt to measure performance thresholds empirically in family and non-family firms and examine their crucial role in driving firms' exit strategies. As such, it demonstrates the key role of performance thresholds in explaining family firms' exit where family owners' decisions are generally driven by nonfinancial factors. In so doing, we extend Gimeno et al.'s (1997) work through our conceptual and empirical investigation of the implications of performance threshold on business exit in the context of emotionally driven family firms. Burgelman (1994), among others, argues that exit may be undermined when emotional logic prevails over business logic. DeTienne (2010, p. 210) theorizes that, when founders and their heirs become so highly "emotionally involved in their venture to the point that it becomes part of their identity," then "not only are they less likely to develop an exit strategy early in the life of the firm, they are less likely to consider one over time." Our focus on differences in performance thresholds between family and non-family firms has important implications for the exit process. Specifically, by identifying performance threshold as a crucial mediating mechanism influencing family firm exit, we help clarify why family firms may be willing to sustain below-target performance owing to nonfinancial considerations while avoiding or delaying business exit decisions.

Our study also responds to recent calls to expand studies of exit processes in family firms beyond the founder's succession (DeTienne and Chirico, 2013; Shepherd, 2009; Ucbasaran et al., 2013; Wennberg et al., 2010). Exit is an important yet underexplored process for entrepreneurs, perhaps because it is a complex multi-level and multi-faceted phenomenon (DeTienne, 2010; Wennberg et al., 2010). This study helps resolve a tension in the family literature regarding family firm exit and contributory factors (Salvato et al., 2010; Wilson et al., 2013) by offering compelling arguments that nonfinancial attributes may affect family firms' attitudes toward different performance levels and their related decisions to exit. Given the prevalence of family firms worldwide and the strategic importance of exit decisions, this study makes an important contribution to the exit literature by shedding light on why family firms' owners decide to persist with their ventures. Our post hoc analyses reveal that family firms are more likely than nonfamily firms to continue and to resist different forms of exit (closure, M\&A) owing to their lower performance thresholds.

Our study also reveals that exit decisions are particularly difficult for firms owned and ran by families. Based on our examination of a larger, longitudinal database and investigation of self-identified first-generation family firms, it seems quite feasible that the longer a family firm exists, the more difficult exit decisions become. As Salvato et al. (2010, p. 322) note, "The generational shadow casts an enduring effect as ancestors' pathways are considered sacred grounds ... Each generation begins to view itself as a steward of the past legacy in the form of their family business." However, our finding that even first-generation family firms have lower exit rates than non-family firms provides insight into how rapidly the family begins to identify with the firm, develop a performance threshold, and make decisions about long-term continuation. While previous studies indicate that older family firms are less likely to divest (Dehlen et al., 2014), ours is the first to show that this tendency arises early in the life of the family firm. 
Furthermore, this work contributes to a growing body of exit research that seeks to gain a better understanding of the dynamics of both firm and entrepreneurial exit and why some firms persist even though their performance may indicate they should exit (or be selected out of) the market. Our paper advances this research by developing a perceptual measure of thresholds that reinforces Gimeno et al.'s (1997) work. Just as the pain threshold may help explain why some individuals take more pain medicine or return to work earlier, the performance threshold indicates why some founders/family members make decisions to persist. In doing so, this research implies that various contextual factors may contribute to thresholds beyond family firms. For example, if family firm control affects thresholds, other ownership structures (e.g., 100\% founder ownership versus various forms of equity ownership) may do the same. If family member identification affects thresholds, might the level of the founder's personal identity associated with the firm also affect the performance threshold? For example, Justo et al. (2015) demonstrate that women are no less likely to "fail" than men are but are much more likely to exit a venture. They speculate that this may be because men have a stronger identity ("I am the business") than women do. Our measurement, testing, and findings of perceptual thresholds lend credence to other unexplored relationships.

\subsection{Limitations and future research}

This study has some limitations. First, we were limited to a perceptual measure of performance threshold, since threshold is not observable. Future research might explore how firms' actual growth rates relate to their perceived thresholds. ${ }^{3}$ According to Gimeno et al. (1997), the performance threshold is the level of performance below which the owners of an organization will act to dissolve it. We therefore compared expectations of growth between family and non-family firms while controlling for economic performance. Future research might seek to identify thresholds in more detail by mapping out the impact of past growth rates vis-à-vis perceptions. Our finding that family firms have lower performance thresholds than non-family firms is important. Differences in performance threshold between entrepreneurs are not yet well understood, and future research might explore whether there are systematic differences in aspirations

\footnotetext{
${ }^{3}$ We thank an anonymous reviewer for this comment.
}

between family owners and whether different family attributes interact with performance thresholds. Several important relationships emerge from our control variables that may form the basis for future applications of threshold theory within and outside family firms. For example, entrepreneurs with college education have consistently higher performance thresholds, whereas firms with higher revenues have lower performance thresholds. Relatedly, although they did not directly test performance thresholds, DeTienne and Cardon (2012) use a threshold argument to examine family succession. They contend that higher education will result in a higher performance threshold and find that education is negatively related to a family succession exit strategy. Similarly, Siepel et al. (2017) examined founders' thresholds for exit, finding that lack of managerial skills is associated with lower thresholds, but that this varies with the age of the firm. Further research might explore whether other attributes of the firm or owner characteristics interact with performance thresholds, such as how the presence of a non-family CEO, the size, and experience of the board of directors and other board characteristics (Wilson et al., 2013) may influence performance thresholds and exits in the family context.

Our study examined firm exits in firms based in the USA. The generalizability of our results is thus limited, and future research should examine exits in different countries and contexts. Furthermore, as this study focused on privately owned firms, it would be interesting to examine exits by publicly traded companies to establish whether they behave differently from privately held firms, given their greater competition and market pressures.

Researchers might also consider investigating performance thresholds in other contexts that, similarly to family firms, arouse intense emotional commitment to the business. These might include ventures with a strong social or sustainable component and those where the founder is passionate about the firm's ability to contribute to societal wealth (Sarason and Hanley, 2015). Researchers should thus consider including performance thresholds in research on exits in social ventures (Austin et al., 2006; Lortie, 2015, p. 228). Other ventures with intense emotional commitments might include those resulting from a personal passion, such as golf (e.g., a new type of club or golf game) or music (online training or adaptations of existing musical instruments to new genres). Other contexts may prove to have varying performance thresholds, thereby helping to explain why some firms persist over long periods 
with poor performance and why some firms exit the market with high levels of performance.

In summary, our study contributes to sharpening our understanding of exit in family firms while motivating future work on exit strategies in family firms and other contexts.

Acknowledgements The authors thank the editor Cristina Bettinelli and two anonymous reviewers for their constructive comments and guidance. The comments of participants at the Academy of Management conference (2015) also helped improve the quality of this work.

Funding Open access funding provided by Jönköping University. This research was supported by the Ewing Marion Kauffman Foundation through access to the KFS data in the NORC Data Enclave.

Open Access This article is licensed under a Creative Commons Attribution 4.0 International License, which permits use, sharing, adaptation, distribution and reproduction in any medium or format, as long as you give appropriate credit to the original author(s) and the source, provide a link to the Creative Commons licence, and indicate if changes were made. The images or other third party material in this article are included in the article's Creative Commons licence, unless indicated otherwise in a credit line to the material. If material is not included in the article's Creative Commons licence and your intended use is not permitted by statutory regulation or exceeds the permitted use, you will need to obtain permission directly from the copyright holder. To view a copy of this licence, visit http://creativecommons. org/licenses/by/4.0/.

\section{References}

Akhter, N. (2016). Family business portfolios: Enduring entrepreneurship and exit strategies, Doctoral dissertation. Jönköping International Business School, Jönköping University.

Akhter, N., Sieger, P., \& Chirico, F. (2016). If we can't have it, then no one should: Shutting down versus selling in family business portfolios. Strategic Entrepreneurship Journal, 10(4), 371-394.

Audretsch, D. B., \& Mahmood, T. (1995). New firm survival: New results using a hazard function. The Review of Economics and Statistics, 77(1), 97-103.

Austin, J., Stevenson, H., \& Wei-Skillern, J. (2006). Social and commercial entrepreneurship: Same, different, or both? Entrepreneurship Theory and Practice, 30(1), 1-22.

Baron, R. M., \& Kenny, D. A. (1986). The moderator-mediator variable distinction in social psychological research: Conceptual, strategic, and statistical considerations. Journal of Personality and Social Psychology, 51(6), 1173-1182.

Berrone, P., Cruz, C., \& Gomez-Mejia, L. R. (2012). Socioemotional wealth in family firms: Theoretical dimensions, assessment approaches, and agenda for future research. Family Business Review, 25(3), 258-279.
Berrone, P., Cruz, C., Gomez-Mejia, L. R., \& Larraza-Kintana, M. (2010). Socioemotional wealth and corporate responses to institutional pressures: Do family-controlled firms pollute less? Administrative Science Quarterly, 55(1), 82-113.

Block, J. H. (2012). R\&D investments in family and founder firms: An agency perspective. Journal of Business Venturing, 27(2), 248-265.

Burgelman, R. A. (1994). Fading memories: A process theory of strategic business exit in dynamic environments. Administrative Science Quarterly, 39(1), 24-56.

Chirico, F., Gomez-Mejia, L. R., Hellerstedt, K., Withers, M., \& Nordqvist, M. (2020). To merge, sell or liquidate? Socioemotional wealth, family control, and the choice of business exit. Journal of Management, 46(8), 1342-1379.

Chirico, F., Salvato, C., Byrne, B., Akhter, N., \& Arriaga Múzquiz, J. (2018). Commitment escalation to a failing family business. Journal of Small Business Management, 56(3), 494-512.

Chirico, F., Sirmon, D. G., Sciascia, S., \& Mazzola, P. (2011). Resource orchestration in family firms: Investigating how entrepreneurial orientation, generational involvement, and participative strategy affect performance. Strategic Entrepreneurship Journal, 5(4), 307-326.

Chrisman, J. J., \& Patel, P. C. (2012). Variations in R\&D investments of family and nonfamily firms: Behavioral agency and myopic loss aversion perspectives. Academy of Management Journal, 55(4), 976-997.

Chua, J. H., Chrisman, J. J., \& Sharma, P. (1999). Defining the family business by behavior. Entrepreneurship Theory and Practice, 23(4), 19-39.

Covin, J., \& Miles, M. (1999). Corporate entrepreneurship and the pursuit of competitive advantage. Entrepreneurship Theory and Practice, 23(3), 47-63.

Cox, D. R. (1972). Regression models and life-tables. Journal of the Royal Statistical Society. Series B (Methodological), 34(2), 187-220.

Cruz, C., \& Nordqvist, M. (2012). Entrepreneurial orientation in family firms: A generational perspective. Small Business Economics, 38(1), 33-49.

Deephouse, D. L., \& Jaskiewicz, P. (2013). Do family firms have better reputations than non-family firms? An integration of socioemotional wealth and social identity theories. Journal of Management Studies, 50(3), 337-360.

Dehlen, T., Zellweger, T., Kammerlander, N., \& Halter, F. (2014). The role of information asymmetry in the choice of entrepreneurial exit routes. Journal of Business Venturing, 29(2), 193-209.

Dencker, J. C., Gruber, M., \& Shah, S. K. (2009). Pre-entry knowledge, learning, and the survival of new firms. Organization Science, 20(3), 516-537.

DesRoches, D., Robb, A., \& Mulcahy, T. M. (2010). Kauffman Firm Survey (KFS) - Baseline/First/Second/Third/Fourth Follow-Ups: Study Metadata Documentation. https://doi. org/10.2139/ssrn.1024312.

DeTienne, D. R. (2010). Entrepreneurial exit as a critical component of the entrepreneurial process: Theoretical development. Journal of Business Venturing, 25(2), 203-215.

DeTienne, D. R., \& Cardon, M. (2012). Impact of founder experience on exit intentions. Small Business Economics, 38(4), 351-374. 
DeTienne, D. R., \& Chirico, F. (2013). Exit strategies in family firms: How socioemotional wealth drives the threshold of performance. Entrepreneurship Theory and Practice, 37(6), 1297-1318.

DeTienne, D. R., McKelvie, A., \& Chandler, G. N. (2015). Making sense of entrepreneurial exit strategies: A typology and test. Journal of Business Venturing, 30(2), 255-272.

DeTienne, D. R., Shepherd, D. A., \& De Castro, J. O. (2008). The fallacy of 'only the strong survive': The effects of extrinsic motivation on the persistence decisions for under-performing firms. Journal of Business Venturing, 23(5), 528-546.

Francis, D. H., \& Sandberg, W. R. (2000). Friendship within entrepreneurial teams and its association with team and venture performance. Entrepreneurship Theory and Practice, 25(2), 5-25.

Gedajlovic, E., Carney, M., Chrisman, J. J., \& Kellermanns, F. W. (2012). The adolescence of family firm research: Taking stock and planning for the future. Journal of Management, 38(4), 1010-1037.

Geroski, P. A., Mata, J., \& Portugal, P. (2010). Founding conditions and the survival of new firms. Strategic Management Journal, 31(5), 510-529.

Gimeno, J., Folta, T. B., Cooper, A. C., \& Woo, C. Y. (1997). Survival of the fittest? Entrepreneurial human capital and the persistence of underperforming firms. Administrative Science Quarterly, 42(4), 750-783.

Gómez-Mejía, L. R., Haynes, K. T., Núñez-Nickel, M., Jacobson, K. J. L., \& Moyano-Fuentes, J. (2007). Socioemotional wealth and business risks in family-controlled firms: Evidence from Spanish olive oil mills. Administrative Science Quarterly, 52, 106-137.

Gómez-Mejía, L. R., Makri, M., \& Kintana, M. L. (2010). Diversification decisions in family-controlled firms. Journal of Management Studies, 47(2), 223-252.

Gómez-Mejía, L. R., Makri, M., \& Kintana, M. L. (2011). The bind that ties: Socioemotional wealth preservation in family firms. Academy of Management Annals, 5(1), 653-707.

Graves, C., \& Thomas, J. (2004). Internationalisation of the family business: A longitudinal perspective. International Journal of Globalisation and Small Business, 1(1), 7-27.

Green, S., Welsh, M., \& Dehler, G. (2003). Advocacy, performance, and threshold influences on decisions to terminate new product development. Academy of Management Journal, 46(4), 419-434.

Guenther, C., Oerter, S., \& Walgenbach, P. (2016). It's all about timing: Age-dependent consequences of founder exits and new member additions. Entrepreneurship Theory and Practice, 40(4), 843-865.

Hecker, D. E. (2005). High-technology employment: A NAICSbased update. Monthly Labor Review, 128(7), 57-72.

Hoskisson, R. E., Chirico, F., Zyung, J., \& Gambeta, E. (2017). Managerial risk taking: A multitheoretical review and future research agenda. Journal of Management, 43(1), 137-169.

Justo, R., DeTienne, D., \& Sieger, P. (2015). Failure or voluntary exit? Re-assessing the female underperformance hypothesis. Journal of Business Venturing, 30(6), 775-792.

Kaye, K. (1998). Happy landings: The opportunity to fly again. Family Business Review, 11(3), 275-280.

Kellermanns, F. W., \& Eddleston, K. A. (2006). Corporate entrepreneurship in family firms: A family perspective. Entrepreneurship Theory and Practice, 30(6), 809-830.
Kellermanns, F. W., Eddleston, K. A., Sarathy, R., \& Murphy, F. (2012). Innovativeness in family firms: A family influence perspective. Small Business Economics, 38(1), 85-101.

Ling, Y., \& Kellermanns, F. W. (2010). The effects of family firm specific sources of TMT diversity: The moderating role of information exchange frequency. Journal of Management Studies, 47(2), 322-344.

Lortie, J. (2015). For the greater good: Why and how social entrepreneurs exit social ventures. In D. R. DeTienne \& K. Wennberg (Eds.), Research handbook of entrepreneurial exit (pp. 226-245). Cheltenham: Edward Elgar.

Mazzola, P., Sciascia, S., \& Kellermanns, F. W. (2013). Nonlinear effects of family sources of power on performance. Journal of Business Research, 66(4), 568-574.

Meyer, M. W., \& Zucker, L. G. (1989). Permanently failing organizations. Newbury Park: SAGE Publications.

Mortara, L., \& Parisot, N. (2018). How do fab-spaces enable entrepreneurship? Case studies of 'makers' - entrepreneurs. International Journal of Manufacturing Technology and Management, 32(1), 16-42.

Pierce, J. L., Kostova, T., \& Dirks, K. T. (2003). The state of psychological ownership: Integrating and extending a century of research. Review of General Psychology, 7(1), 84-107.

Rabe-Hesketh, S., \& Skrondal, A. (2008). Multilevel and longitudinal modeling using Stata (2nd ed.). College Station: Stata Press.

Salvato, C. (2004). Predictors of entrepreneurship in family firms. Journal of Private Equity, 7(3), 68-76.

Salvato, C., Chirico, F., \& Sharma, P. (2010). A farewell to the business: Championing exit and continuity in entrepreneurial family firms. Entrepreneurship and Regional Development, 22(3-4), 321-348.

Sarason, Y., \& Hanley, G. (2015). Social ventures: Exploring entrepreneurial exit strategies with a structuration lens. In D. R. DeTienne \& K. Wennberg (Eds.), Research handbook of entrepreneurial exit (pp. 214-225). Cheltenham: Edward Elgar.

Shah, K. S., \& Winston Smith, S. (2012). Intellectual property, prior knowledge and the survival of new firms. Paper delivered at the Strategic Management Society Annual International Conference, Rome, Italy.

Shane, S., \& Stuart, T. (2002). Organizational endowments and the performance of university start-ups. Management Science, 48(1), 154-170.

Sharma, P., \& Manikutty, S. (2005). Strategic divestments in family firms: Role of family structure and community culture. Entrepreneurship Theory and Practice, 29(3), 293-311.

Shepherd, D. A. (2009). Grief recovery from the loss of a family business: A multi- and meso-level theory. Journal of Business Venturing, 24(1), 81-97.

Siebels, J. F., \& Zu Knyphausen-Aufseß, D. (2012). A review of theory in family business research: The implications for corporate governance. International Journal of Management Reviews, 14(3), 280-304.

Siepel, J., Cowling, M., \& Coad, A. (2017). Non-founder human capital and the long-run growth and survival of high-tech ventures. Technovation, 59, 34-43.

Sirmon, D. G., Arregle, J.-L., Hitt, M. A., \& Webb, J. W. (2008). The role of family influence in firms' strategic responses to threat of imitation. Entrepreneurship Theory and Practice, 32(6), 979-998. 
Sirmon, D. G., \& Hitt, M. A. (2003). Managing resources: Linking unique resources, management, and wealth creation in family firms. Entrepreneurship Theory and Practice, 27(4), 339358.

Sobel, M. E. (1982). Asymptotic confidence intervals for indirect effects in structural equation models. Sociological Methods, 13, 290-312.

Staw, B. M. (1981). The escalation of commitment to a course of action. Academy of Management Review, 6(4), 577-587.

Stuart, T. E., Hoang, H., \& Hybels, R. C. (1999). Interorganizational endorsements and the performance of entrepreneurial ventures. Administrative Science Quarterly, 44(2), 315-349.

Taylor, M. P. (1999). Survival of the fittest? An analysis of selfemployment duration in Britain. The Economic Journal, 109(454), C140-C155.

Ucbasaran, D., Shepherd, D. A., Lockett, A., \& Lyon, S. J. (2013). Life after business failure: The process and consequences of business failure for entrepreneurs. Journal of Management, $39(1), 163-202$.

Uhlaner, L. M. (2006). Business family as a team: Underlying force for sustained competitive advantage. In P. Z. Poutziouris, K. X. Smyrnios, \& S. B. Klein (Eds.), Handbook of research on family business (pp. 125-144). Cheltenham: Edward Elgar.

Wennberg, K., Wiklund, J., DeTienne, D. R., \& Cardon, M. S. (2010). Reconceptualizing entrepreneurial exit: Divergent exit routes and their drivers. Journal of Business Venturing, 25(4), 361-375.

Wilson, N., Wright, M., \& Scholes, L. (2013). Family business survival and the role of boards. Entrepreneurship Theory and Practice, 37(6), 1369-1389.

Wiseman, R. M., \& Gomez-Mejia, L. R. (1998). A behavioral agency model of managerial risk taking. Academy of Management Review, 23(1), 133-153.

Wolfe, M., \& Patel, P. (2019). To your health: Health insurance, self-employment exit, and older entrepreneurs. Journal of Small Business Management, 57(2), 593-615.

Wooldridge, J. M. (2001). Econometric analysis of cross section and panel data. Cambridge: MIT Press.

Zellweger, T. M., Nason, R. S., Nordqvist, M., \& Brush, C. G. (2013). Why do family firms strive for nonfinancial goals? An organizational identity perspective. Entrepreneurship Theory and Practice, 37(2), 229-248.

Zellweger, T., Sieger, P., \& Halter, F. (2011). Should I stay or should I go? Career choice intentions of students with family business background. Journal of Business Venturing, 26(5), 521-536.

Publisher's note Springer Nature remains neutral with regard to jurisdictional claims in published maps and institutional affiliations. 